\title{
銅ニッケル合金の高温アルゴンスパッタリングによる 表面組成変化と照射誘起拡散の解析
}

\author{
清水肇* 古山直行** 石田洋一***
}

J.Japan Inst.Metals, Vol.45,No.8(1981),pp.768 775

The Sputter-Induced Solute Segregation in the Surface Layer of Cu-Ni Alloys during Argon Ion Bombardment at Elevated Temperatures

Hazime Shimizu*, Naoyuki Koyama** and Yoichi Ishida***

In order to study the mechanism of sputter-enhanced solute segregation, surface and matrix compositions of $\mathrm{Cu}-\mathrm{Ni}$ alloys were measured after $\mathrm{Ar}$ ion bombardment up to $873 \mathrm{~K}$ by means of Auger electron spectroscopy (AES) and X-ray micro analysis (XMA). Sputtering at a high dose rate resulted in nickel enrichment on surface at all temperatures and all alloy compositions. At low dose rate, however, copper was sezregated in the surface. The thickness of segrezated copper layer was $4 \sim 6 \mathrm{~nm}$ at $873 \mathrm{~K}$ that was tos thick to be the Gibbsian equilibrium serregation. A layer depleted in copper $\sim 70 \mathrm{~nm}$ in thickness was observed beneath it. In order to know the deth profile, the composition change was analyzed and the enhanced diffusion was measured with a 40 at \% coarse grained specimen ( $1 \sim 2 \mathrm{~mm}$ in diameter). The enhancements of diffusion coefficients were $3.6 \times 10^{8}, 1.3 \times 10^{4}$ and 19 at 573,723 and $873 \mathrm{~K}$, respectively. The apparent activation energy was only $22.6 \mathrm{~kJ} / \mathrm{mol}$. The small value suggested that the surface segregation was caused by the interstitial type diffusion mechanism.

(Received March 4. 1981)

\section{I. 緒 言}

銅ニッケル合金は選択スパッダリングの研究の基礎系と して重視され，数多〈の報告がある. Tarng とWehner ${ }^{(1)}$ ならびに筆者ら(2)室温でこの合金にアルゴンイオン衝撃 を行うと，表面がニッケルで富化されることをLMMオー ジニピークの定量により明らかにし，その変化が単体の銅 とニッケルとのスパッタ率から説明出来るモデルを示し た ${ }^{(3)}$. Watanabe ら ${ }^{(4)}$ は脱出深さのより浅いMMMオージ ニピークを用いると，最外層のニッケル富化度合はさらに 大きくなることを示し，Ho $5^{(5)(6)}$, Saeki とShimizu ${ }^{(7)}$ は表面から内部にかけて組成変化している領域を変質層 (Altered layer) 々呼び，その深さは数 nm で入射イオン の飛程と良く対応していることを示した。また Goto ら ${ }^{(8)}$ と Koshikawa $ら^{(9)}$ は液体空素温度近傍です選択スパッタ リング現象が起ることを確認し，室温で起るニッケル富化 が少なくとも入射イオンが形成する表面近傍の格子欠陷に よる母相内での原子の空孔型拡散に寄因するものでないこ とを明らかにした。 また Brongersma ら ${ }^{(10)}$, Okutaniら(11) はイオン散乱分光法(ISS)を用いて，選択スパッタリング を受けた表面の最外第 1 層は銅がやや富化していると報告 している，選択スパッタリング現象を理解する上て変質層
内での組成分布やこの合金の持つ銅の表面偏析効果を明ら か烧要がある。柿林ら(12)はイオンマイクロアナラ イザー(IMA)を用いてこれらの議論を行った. Saeki と Shimizu ${ }^{(13)}$ によってスパッタ堆積膜の組成解析む行なわ れている。

筆者ら ${ }^{(11)}$ は銅ニッケル合金を高温でイオン衝撃すると， 表面のニッケル富化度合が室温の場合より強调されること を才ージェ電子分光法 (AES) で明らかにし，照射誘起拡散 の表面組成変化への役割を指摘した。またX線マイクロア ナリンス法(XMA)を併用することによって，(a)表面組成 変化が入射イオン密度と温度之の依存性を示す ${ }^{(15)}$ ，(b)照 射条件によって表面下数百 $\mathrm{nm}$ 亿执よが銅欠乏層が形成さ れる，(c) 粶界移動や粒界昖散が重要になることを報告し $た^{(16)(17)}$, Rehn ら ${ }^{(18)} な ら ひ ゙ に ~ S h i k a t a ~ と S h i m i z u^{(19)}$ に よっても高温スパッタリングによる銅欠之層の解析がなさ れている。

本研究では特仁結晶粒内での照射誘起拡散現象を検討す るために, 平均粒径が $\phi 1 \sim 2 \mathrm{~mm} の 40 \mathrm{at} \% \mathrm{Ni}$ 合金の粗 大粒試料を用いてより定量的な実験を試み，(a)銅欠之層 に及注方照射条件の解析，(b) 照射誘起拡散定数, 活性化 エネルギーの算出を行ら。をの結果にもとづき高温スパッ タリングの機構を解析する。

* 電子技術総合研究所 (Electrotechnical Laboratory, Sakura-mura, Niihari-gun, Ibaraki)

*** 東京大学大学院 (Graduate School, University of Tokyo, Tokyo)

*** 東京大学生産技術研究所 (Institute of Industrial Science, University of Tokyo, Tokyo) 


\section{II. 実 験}

\section{1. 試料}

銅ニッケル合金の多結晶試料は，銅(99.99at\%)と二 ッケル $(99.9$ at \%) を真空溶解し，10 at\%扣きに 9 種類 作成した，溶解後熱間ならびに冷間圧延により約 0.15 $\mathrm{mm}$ の板厚にした．任延による歪の除去と結晶粒径成長の ために, 試料を $10^{-3} \mathrm{~Pa}$ 台の真空炉に入れて 10 時間以上 焼鈍した、ニッケル含有率が高くなるほど再結晶温度が高 くなるために，同一燃鐩温度では平均粒徍住組成依存性が 認められ，40 at\% Ni 合金の場合には $1273 \mathrm{~K}$ に保つこと で中粒試料 $(\phi 200 \sim 400 \mu \mathrm{m})$ 方得られた。粗大粒試料 $(\phi 1 \sim 2 \mathrm{~mm})$ は中粒試料に再度軽い冷間加工を行った後に 融点近傍で焼鈍して得た。リン酸，硫酸，水混合液中で試 料に電解研磨を施し，焼錐による表面の污れや銅欠乏層を 除去した ${ }^{(20)}$. 電解研磨による結唱粒界の侵食の少ない鏡 面が得られた。

\section{2. 組成分析}

組成の分析には自作の走査型 AES 装置と KEVEX 社の エネルギー分散型 XMAを用いた。オージェ分析には銅と

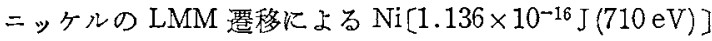
と $\mathrm{Cu}\left[1.472 \times 10^{-16} \mathrm{~J}(920 \mathrm{eV})\right]$ の 2 本のピークを用いた. 表面最外層の組成分析には脱出深さの浅い MMM 镸移 $\left[\sim 1.68 \times 10^{-17} \mathrm{~J}(105 \mathrm{eV})\right]$ が適しているが，本研究の目的 は表面下 $120 \mathrm{~nm}$ に扔よぶ組成の深さ力向分析であるため

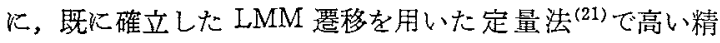
度が得られると考えられる、X線分析には二ッケルの $\mathrm{K}_{\boldsymbol{x}_{1}}$ ， $\mathrm{K}_{\alpha_{2}}\left[1.196 \times 10^{-15} \mathrm{~J}(7477 \mathrm{eV}), 1.194 \times 10^{-15} \mathrm{~J}(7460 \mathrm{eV})\right]$ と銅の $\mathrm{K}_{\alpha_{1}}, \mathrm{~K}_{\alpha_{2}}\left[1.287 \times 10^{-15} \mathrm{~J}(8046 \mathrm{eV}), 1.284 \times 10^{-15} \mathrm{~J}\right.$ $(8026 \mathrm{eV})]$ ピークを用いた。エホルギー分析器の分解能が

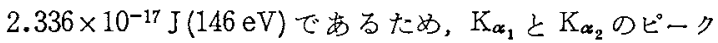
は分離出来なかった，定量分析の精度は AESで士5\%， $\mathrm{XMA}$ で $\pm 2 \%$ 程度であった，AES 装置の位置分解能は， 電子の加速電圧 $10 \mathrm{kV}$ で試料電流を $3 \times 10^{-7} \mathrm{~A}$ とると約 $3 \mu \mathrm{m}$ であった ${ }^{(22)}$. 本研究では多結晶試料表面の平均組成 について得た結果を報告する。

スパッタ中に放出される原子の組成は，試料前に取り付 けたチタン板に堆積させた薄膜をXMA で分析した。チタ ンの特性X線は銅とニッケルとの $\mathrm{K}_{\boldsymbol{\alpha}_{1}}, \mathrm{~K}_{\boldsymbol{\alpha}_{2}}$ ピークと重な り合わないのでュレタター材として適している。この実験 では鉰とニッケルとの付着率は同じと仮定した。また高温 スパッタ中は試料からの輻射によってコンクターの温度も 上䄯すると考えられるが，温度測定はしなかった。放出角 度による組成差は無視して平均值を求め心 ${ }^{(23)}$.

\section{3. イオン照射}

真空装置は分子ポンプとイホンポンプで排気され，423

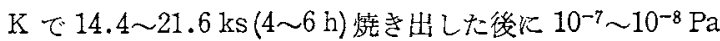

の到達在力が得られた。残留ガスは $\mathrm{H}_{2}, \mathrm{CH}_{4}, \mathrm{H}_{2} \mathrm{O}, \mathrm{CO}$, $\mathrm{CO}_{2}$ などである。イオン照射中は分子ポンプで差動排気 し, $10^{-3} \mathrm{~Pa}$ 台のアルジンを導入した。残留ガスの感度 係 数は考虑していないが，王力比から不純物濃度は $10^{-3}$ 以 下に押党られたと考えられる。イオン照射には熱電子衝撃 型のイオン銃を用いた， $3 \mathrm{kV} て ゙$ 加速されたイオンは試料 に垂直に入射するよらに AES 用の試料ホルダーを回転さ せた。イオン電流密度は $2 \times 10^{-3} \mathrm{~A} / \mathrm{m}^{2} \sim 8 \times 10^{-1} \mathrm{~A} / \mathrm{m}^{2}$ の 範囲で変化さ好た。試料に入射するイオン電流を正確に測 定するために，試料面から約 $3 \mathrm{~mm}$ 離れた位置に約 $4 \times 5$ $\mathrm{mm}^{2}$ の開口を持つタンタル薄板を，オージェ電子の軌道 の妨け゚にならない最適位置に取付けた。李た 2 次電子の放 出によるイオン電流の文かけの堌加は，試料に約 $25 \mathrm{~V}$ の バイアス電王を印加して補正したが，2次イオンによる影 響は考慮しなかった。ビーム形状による不均一性は X, Y 方向に電気的に掃引することで解決した。

室温でイオン衝撃を行った表面を AES で測定すると炭 素ピークの成長が認められる。イオン衝撃によって活性化 された表面に，電流密度の高い電子ビームによって残留ガ スが堆積したものと考えられる。この効果は高温でイオン 衝撃した表面では弱いので，焼鈍による表面の回復の問題 とガスの吸着性が関与しているとみられる，試料の漭鈍に よって硫黄の偏析も起るが，イオン衝揧と焼鈍の繰返しに よって次第に弱まる.高温スパッタリング後の表面では硫 黄は全く検出されなかった，表面に存在する不純物によっ て元素の母相からの偏析(本研究ては銅原子)は何らかの影 響は受けると考光られるが，本研究では表面下に形成され た銅の欠之層への影響は少ないものとして解析を行った。

\section{III. 結 果}

\section{1. 室温でイオン衝揧した試料表面近傍への銅の 滲み出し}

室温で銅ニッケル合金をイオン衝撃すると選択スパッタ リングによってニッケル濃度が上昇する。この変化は AES のみで検出されXMA では認められない。この試料を 1023 Kまでの各温度で焼鈍すると，表面の銓濃度が高まる。た とえば 40 at $\% \mathrm{Ni}$ 合金の場合は，イオン衝軗後の趇面ニッ ケル濃度は 55〜57 at\%であるが，423，573，723，873 K の各温度での暁鈍後の平衡組成は $52,50,33,25$ at \% となる。 $873 \mathrm{~K}$ と $1023 \mathrm{~K}$ とではほとど濃度差は認

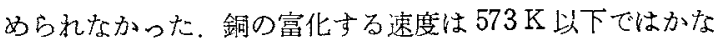
り遅く，平衡状態に到達するまでに 900 1200s 要するが, $723 \mathrm{~K}$ 以上では著しく速く $5 \sim 15 \mathrm{~s}$ 程度である。このた め高温での銅の富化現象を定量的に追跡することは困難で あった。

Fig.1 は 40 at $\% \mathrm{Ni}$ 合金の粗大粞試料を用いて, 各温度 での焼銈によって富化した銅層の厭みをアルダンイオン㩆 離法により推定した絬果である。㩆離速度の目安として， 


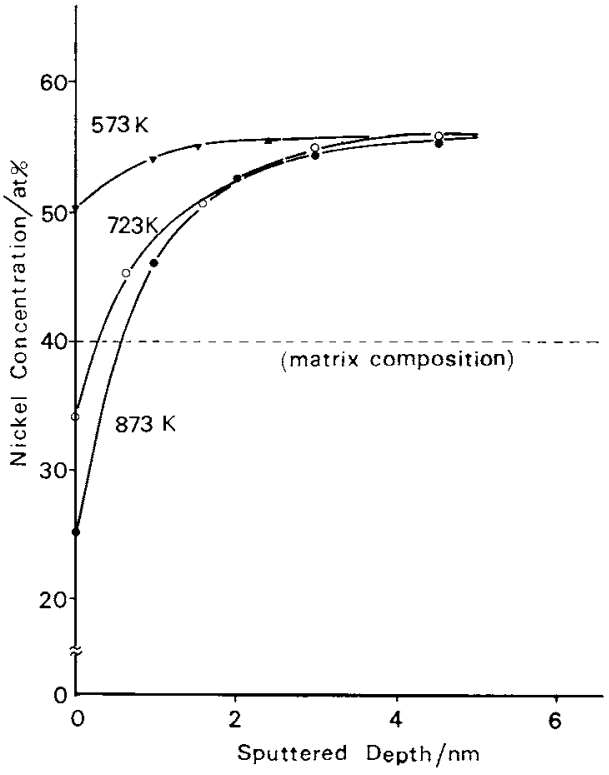

Fig.1 The estimated profile of the copper segregated layer near the surface of a coarse grained 40 at $\% \mathrm{Ni}$ alloy sputtered at room temperature and annealed at various temperatures $K$ for $1.2 \mathrm{ks}$.

$4 \times 10^{-2} \mathrm{~A} / \mathrm{m}^{2}$ のイオン密度に対して(111) 面上の銅原子が $0.36 \mathrm{~nm} / 23 \mathrm{~s}$ の速度で削られるといら計算値を用いた。 この值は合金の組成ならびそ試料の集合組織によっても影 響を受ける. $573 \mathrm{~K}$ では銅富化の度合が弱いが約 $1 \mathrm{~nm}$ 程度と推定された。723，873 K の場合にはほぼ同じで 4〜 $5 \mathrm{~nm}$ であった．AES の分析深さを考慮すると最外層の銅 濃度はさらに高く，深さ方向分布は Fig.1 の結果より鋭く なっていると考党られる ${ }^{(24)}$. 銅富化現象の再現性はかなり 良く，痓鈍前のイオン衝撃時間の長さにはあまり影響され ない.平均粒径の小さい試料を用いると, 銅の富化速度は大 きくなる傾向が認められるが，各温度での平衡銅濃度と銅 富化層の厚みには惊とんど粒径依存性が楒められない， た試料面上の場所による濃度变化る少なかった。以上の結 果から銅は表面ではぼ均一に富化し，その富化速度には表 面の金属組織的な性質が関与すること，富化度合は合金の 熱力学的な性質 (平衡偏析など) で決ると考えられる。

\section{2. 高温スパッタリングによる表面組成変化}

選択スパッタリングによるニッケル富化の傾问々，焼銛 に伴う銅の偏析举動はみかけ上逆向の働をするため，高温 スペッタリングによる表面組成変化は複雑になる。 Fig.2 は $40 \mathrm{at} \% \mathrm{Ni}$ 合金の中粒，粗大試料を $873 \mathrm{~K} て ゙ 1.8 \mathrm{ks}$ イ オン衝撃した後のAES で求めた表面組成変化の入射イオ ン密度依存性である。試料温度が一定になった後にイオン 照射を開始し，1.8ks 後に加熱とイオン衝撃を同時に停止 した。試料ホルダーの蓺容量が大きいために試料の降温に 要する時間は 873〜 723 K で5〜7 s, 723〜 573K では 30〜 $40 \mathrm{~s}$ であった。 $723 \mathrm{~K}$ 以上での銅の偏析速度が大きいこと

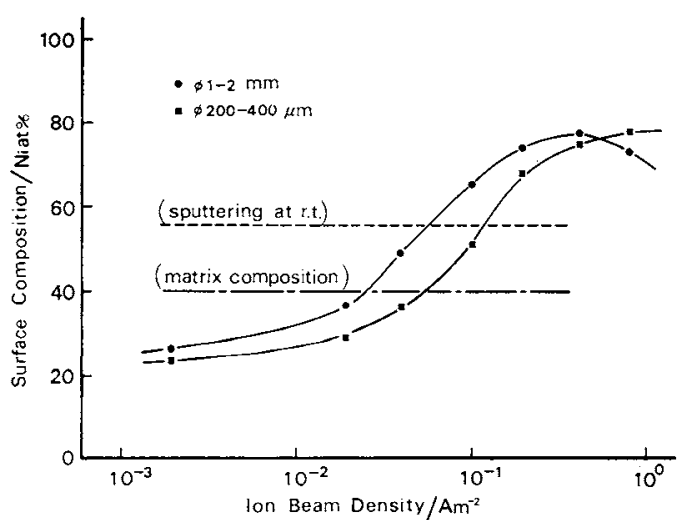

Fig.2 The effect of Ar ion dose rate on the surface composition of 40 at $\% \mathrm{Ni}$ alloy specimens with varied grain diameter. Ion bombardment was carried out at $873 \mathrm{~K}$ for $1.8 \mathrm{ks}$.

を考虑すると，Fig.2の結果には降温中に受汁る銅富化の 影響が含まれていると考光られるが，本研究では無視し た.

Fig.2の結果からかなり広いイオン密度の範囲で表面組 成変化洁晶粒径依存性が認められる。低イオン密度では 銅の偏析速度が䟝離速度を上まわり，しかも結晶粒径が小 さいすが偏析速度が大きいことを示している． $4 \times 10^{-1} \mathrm{~A} /$ $\mathrm{m}^{2}$ のイオン密度に対しては，中粒，粗大粒いずれの試料 でも表面組成は $1.2 \mathrm{ks}$ 程度の衝撃で平衡状態になるが， イオン密度が低い昜合にはニッケル濃度は僅かながら增加 する傾向が認められるので，Fig.2の結果は過渡的なるの とす考えられる.イオン密度の增加ととすに双方の試料で ニッケル富化が起り始め，室温スパッタリングに扣ける平

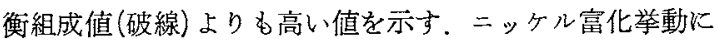
は粒径依存性があって，粒径が小さい試料では破線を越克 るのに必要なイオン密度が高い, 高いイオン密度になると 粒径による差が小さくなることは，表面の㔀離速度が銅の 滲及出し速度を十分上まわってくることを示す。

Fig.3は $4 \times 10^{-1} \mathrm{~A} / \mathrm{m}^{2}$ のイオン密度で組成を变えた合 金を $1.8 \mathrm{ks}$ 間各温度で衝撃した後の表面組成を AES で 測定した結果である，試料の平均粒径を広い組成範囲で揃 党ることが出来なかったので，中粒試料のららで比較的粒 径の大きいすのを選んで実験に用いた，いずれの合金組成 でも室温イオン衝撃の場合よりもニッケル富化が促進され る。ニッケルが最す富化する舟相合金組成は，室温の場合 には 40〜60 at\% Ni の領域であるが，温度が高くなるにつ

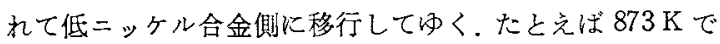
は 20,40 at $\% \mathrm{Ni}$ 合金で最もニッケルが富化し，それぞれ 52,78 at $\% \mathrm{Ni}$ 相当の組成となり $32 \sim 38$ at \% むのニッケル 富化が起る。

各温度での表面組成はパラメター $R$ を用いると，次式 で示される計算值と広範囲の母相合金組成に対して良い一 致を示主.

$$
m / n=R \cdot a / b
$$




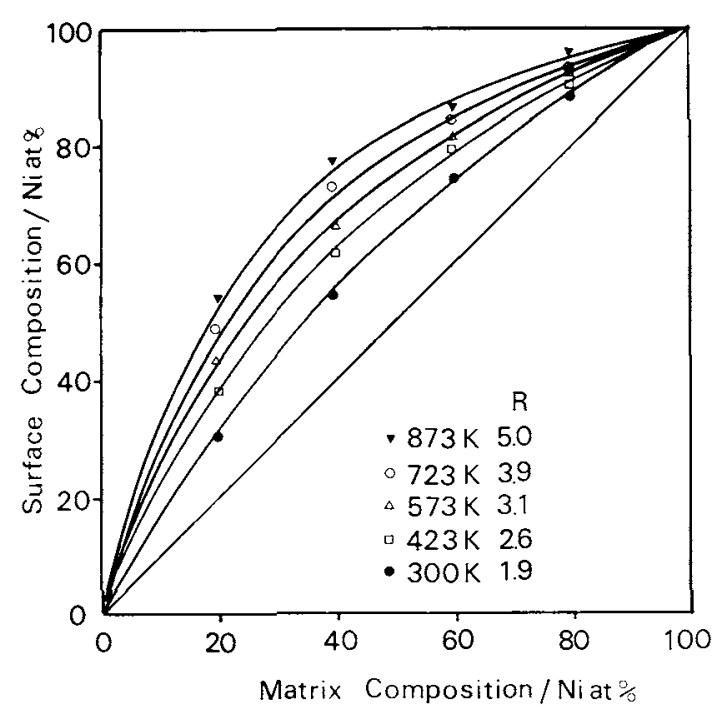

Fig.3 The surface composition of $\mathrm{Cu} / \mathrm{Ni}$ alloys (diameter $200 \sim 400 \mu \mathrm{m}$ ) after sputtering at argon ion density of $0.4 \mathrm{Am}^{-1}$ for $1.8 \mathrm{ks}$ at elevated temperatures. The parameter $R$ is defined in eq. (1).

ここで $m / n$ はES で求めた表面のニッケルと銅の濃度 此， $a / b$ は同しく母相組成に対する值を示す。室温スパ ッタリングの場合の $R$ は $1.9 \pm 0.1$ であるが, 423,573 , $723,873 \mathrm{~K}$ ではそれぞれ 2.6,3.1,3.9,5.0と大きくな る. $873 \mathrm{~K}$ ではやや訪算值とのずれる大さくなるが，それ 以下の温度での再現性はかなり高かった。

\section{3. 母相内組成の深さ方向分析}

$873 \mathrm{~K}$ でイオン衝撃 $\left(4 \times 10^{-1} \mathrm{~A} / \mathrm{m}^{2}\right)$ を 1 時間行った試料 を XMA で分析すると，2〜3at％のニッケル韵化が認め られ，高温スパッタリングの場合には組成变化が起ってい る領域が深くなっていることがわかった.40at\% Ni 合金の

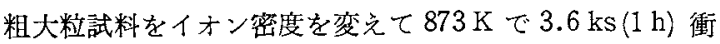
揧した後, 表面から内部にかけて AES で組成分析した結 果を Fig.4に示した。イオン剥離を行うと選択スパッタリ ング效果によって㬰際の濃度よりニッケルが富化した結果 が得られるので，式（1）による補正を行った結果を Fig.4 に示した。な祘 $R$ の值には 1.9 を用いた。

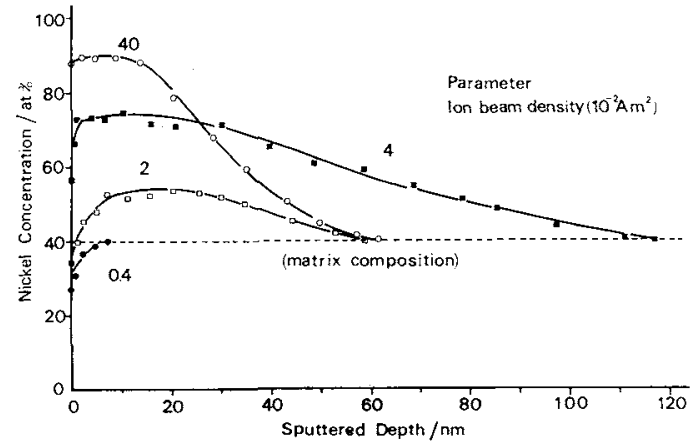

Fig.4 The effect of Ar ion dose rate on the depth profile of a coarse grained 40 at $\% \mathrm{Ni}$ alloy (diameter $1 \sim 2 \mathrm{~mm}$ ) after sputtering at $873 \mathrm{~K}$ for $3.6 \mathrm{ks}$.
$4 \times 10^{-3} \mathrm{~A} / \mathrm{m}^{2}$ で衝撃した後は，28 at\% Ni 相当の組成で あるが，表面層を 6〜7 nm 㔀離すると母相組成にもどる. この結果はFig.1の焼鋱による效果と同じである．高温ス パッタ中にこのイオン密度で $3.6 \mathrm{ks}(1 \mathrm{~h})$ 間に影離された 表面層の厚みは約 $6 \mathrm{~nm}$ であるが，鉰の偏析速度の方がは るかに大さいために，安定な銅富化層が形成されたと考觉 られる。 $2 \times 10^{-2} \mathrm{~A} / \mathrm{m}^{2}$ のイオン密度の場合には,初期の組 成は 36 at \% Ni 相当になり，1〜2 nm 表面層を虽離すると 母相組成にもどる，さらに深く削るとニッケル澧度は 50 at\%まて上った。この組成は $20 \mathrm{~nm}$ 委で保たれた後減少 し始め，60nmぐらいの深さで再び母相組成にもどった. $4 \times 10^{-2} \mathrm{~A} / \mathrm{m}^{2}$ では銅偏析層は全く認められず，表面か ら $30 \mathrm{~nm}$ をで 73 at\% $\mathrm{Ni}$ 程度のニッケル富化層が存在す る、銅欠之層全体の深さは約 $120 \mathrm{~nm}$ であった。. $4 \times 10^{-1}$

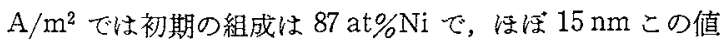
が保たれた後に急激に減少乙銅欠之層の深さは約 $60 \mathrm{~nm}$ となった。入射イオン密度は表面近傍の組成ばかりでな く，母相内の銅の分附状態に鸟影響することが明らかにな った。

イオン衝撃条件によって $120 \mathrm{~nm}$ 程度まで銅の久之層が 形成されたことは，表面の㔀離より速く銅の搪散が起って いることを示す，入射イオンによって格子が乱れた領域で は,ニッタルより結合力の弱い銅の拉散が促進される、一方 表面の熱力学的性質により銅は表面偏析を起すので，銅は イオン衝骜によって優先的に剥離される。内部から表面へ の銅の補紷によって銅の欠之層功形成され始め, 正常な体 执散とイオン照射による促進された㹡散との釣合によって 平衡状態に到達すると考えられる，高密度イオン照射の場 合には約 $1.2 \mathrm{ks} て ゙$ 銅の欠之層が平衡状態になったことは， この間に䟝離される合金の銅濃度が高く，平衡状態では母 相と同一になることを意味する. $4 \times 10^{-3} \mathrm{~A} / \mathrm{m}^{2}$ のよらに 低いイオン密度の照射中でる銅の促進された払散は起って いて，長時間イオン衝慗を続ければ銅の欠乏層は形成され る笘である、したがって Fig.4k和ける久之層の分布は， 低イオン密度ではまだ平衡状態が得られていないと考る必 要がある。

\section{4.スパッ夕膜の XMAによる組成解析}

スパッタ膜のXMAKよる分析から母相内の銅欠之層の 検討を行った，Fig.5 は照射イオン量を一定 $\left(4 \times 10^{-1} \mathrm{~A} /\right.$ $\left.\mathrm{m}^{2} \cdot 7.2 \mathrm{ks}\right)$ に保つよらに入射イオン密度と照射時間を変克 て $873 \mathrm{~K}$ でイオン衝撃した 40 at\% $\mathrm{Ni}$ 中粒試料の結果であ る。照射イオン量は銅に換算して䄪 $1.1 \mu \mathrm{m}$ の表面層を㔀 離したことになるが，堆積した薄膜の桪みは $100 \mathrm{~nm}$ 以下 と考えられ，下地チタンピークが強く現かれた. $4 \times 10^{-1}$ $\mathrm{A} / \mathrm{m}^{2}$ で $7.2 \mathrm{ks}(2 \mathrm{~h})$ 照射した試料の母相平均組成は約 37 at\% $\mathrm{Ni}$ で僅かながら銅の欠之が認められ，一方対応した 薄膜の組成は 42〜3at\%であった，前節で述べたように， この条件では約 $1.2 \mathrm{ks}$ 間で欠ミ層が定常状態になるので， 


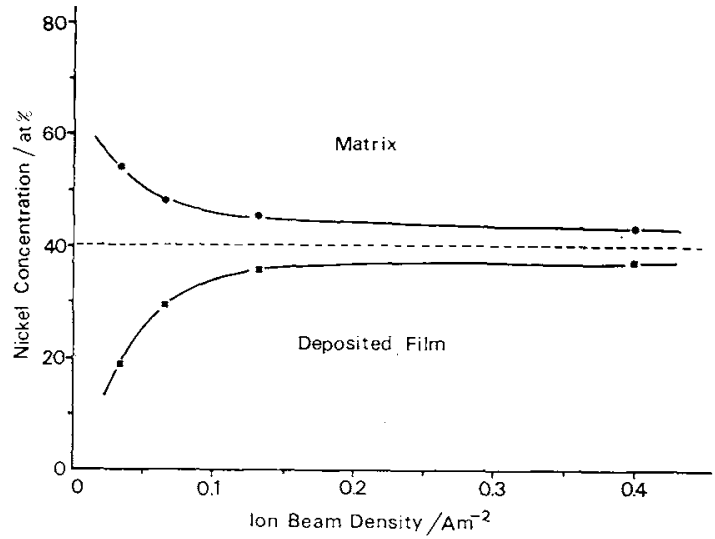

Fig.5 The composition of the matrix and the sputter-deposited film of a 40 at $\% \mathrm{Ni}$ alloy (diameter 200 $\sim 400 \mu \mathrm{m})$ measured by XMA after sputtering for various ion dose rates at $873 \mathrm{~K}$. The total ion dose was kept constant at $2.88 \times 10^{3} \mathrm{~A} \cdot \mathrm{m}^{-2}$.

残りの $6.0 \mathrm{ks}$ は母相組成を保ったまま䟝離が進行する。 このため母相と薄膜との間に著しい組成差が認められな い. $1.3 \times 10^{-1} \mathrm{~A} / \mathrm{m}^{2}$ のイオン密度でああ委り差がないが， $6.6 \times 10^{-2} \mathrm{~A} / \mathrm{m}^{2}, 3.3 \times 10^{-2} \mathrm{~A} / \mathrm{m}^{2}$ の照射条件では母相の 組成は 48 at $\% \mathrm{Ni}, 55$ at\% Ni に，また対応する薄膜の組成 は 30 at \% Ni, 20 at \% Ni になり，イオン密度の低下ととも に銅の優先的㔀離が進行し，それに伴って母相内に深い欠 乏層が形成されてゆくことを示している。

先の報告〈17\}で示したように秸晶粒界に沼っての深い銅 の久乏層は本研究でも確認された，母相の平均組成に粒界 の寄与があると考なければならないが，銅が久乏している 粒界幅は 3〜4 $4 \mathrm{~m}$ であるから算純に面積比をとると1〜2\% 程度と見積られる，したがって母相内の粒内欠乏層のお标 よその深さを議論する上では支障がない。しかし気相に放 出される合金の組成中の銅に関しては閭題が残る。結晶粒 界に沼っての执散は粒内のそれに比較して速いので，面積 比以上の影響が出てくる。低イオン密度の照射によって得 られた海膜中の銅濃度は母相の銅欠之度合より大きくこ れは粒界での銅欠乏に寄因している可能性がある。

\section{5. 照射誘起拡散定数と活性化エネルギ一の算出}

銅欠乏層の解析により㹡散定数と活性化エネルギーの算 出が出来れば、イオン誘起払散機構の検討が出来る. Fig.6 は $4 \times 10^{-1} \mathrm{~A} / \mathrm{m}^{2}$ のイォン密度で 40 at $\% \mathrm{Ni}$ 合金の粗大粒 試料を $573,723,873 \mathrm{~K}$ の各温度で $3.6 \mathrm{ks}(1 \mathrm{~h})$ 照射した 場合の銅欠乏㾘の深さ方向分布である. $873 \mathrm{~K}$ で照射した 場合には約 $1.2 \mathrm{ks}$ で久乏層が定常状態になることを確認 したので，それ以下の温度では物質移動が遅くなることか らより短時間で定常状態加得られたと見なした。

温度が高くなるにつれて銅の欠厤は深くなり，573， $723,873 \mathrm{~K}$ ではそれぞれ $15,42,67 \mathrm{~nm}$ であった。試料温 度はニッケルの富化度合にも影響するために，高温スハッッ

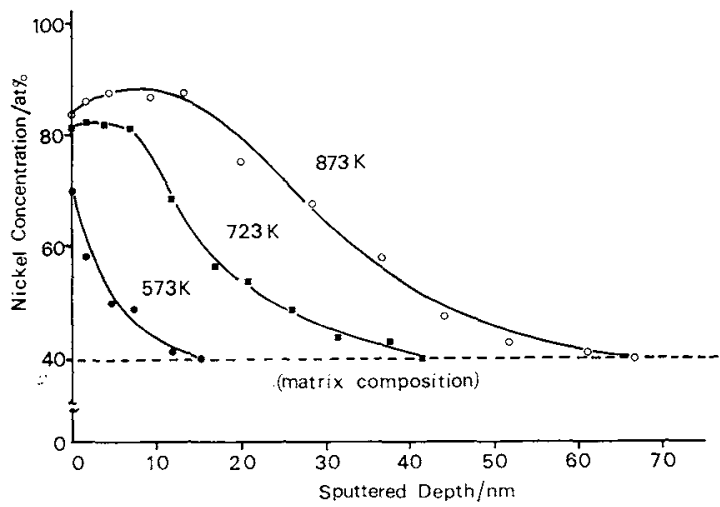

Fig.6 The effect of sputtering temperature on the depth profile of the copper depleted region in a coarse grained 40 at $\% \mathrm{Ni}$ alloy (diameter $1 \sim 2 \mathrm{~mm}$ ), which was bombarded for $3.6 \mathrm{ks}$ at current density of $0.4 \mathrm{Am}^{-2}$.

タ中に優先的に䟝離された銅の量の温度传存性恃，欠乏層 の深さ变化から予想される值より大きくなる. $873 \mathrm{~K}$ と $723 \mathrm{~K}$ では表面近傍でニッケル濃度が一定值を保つ現象が 認められ，払散機構が異なっていることを示缶している。

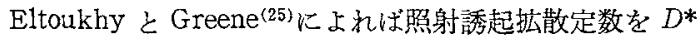
とすると， $D^{*}$ が損傷層領域内で一定の場合には定常状態 における欠之層内の濃度变化は次式で表わされる。

$$
\Theta(x)=C+[\Theta(0)-C] \exp \left(-x v / D^{*}\right)
$$

ここで $\Theta(x)$ は表面から深さ $x$ の場所でのニッケル濃度, $\Theta(0)$ はスパッタ直後の表面二ッケル濃度, Cは母相ニッ ケル濃度を示す。 $v$ はイオンによる表面影離速度で本研究 では $4 \times 10^{-2} \mathrm{~A} / \mathrm{m}^{2}$ のイオン密度に対し $0.016 \mathrm{~nm} / \mathrm{s}$ といら 計算値を用いた．Fig.7は式(2)に従って Fig.6の結果 を解析したるのである．723，873 K の表面近くの欠乏層は 著しく大きな昖散定数を持つことがわかる，それより深い 部分での直線性は良いのでこの領域での桩散定数を求め

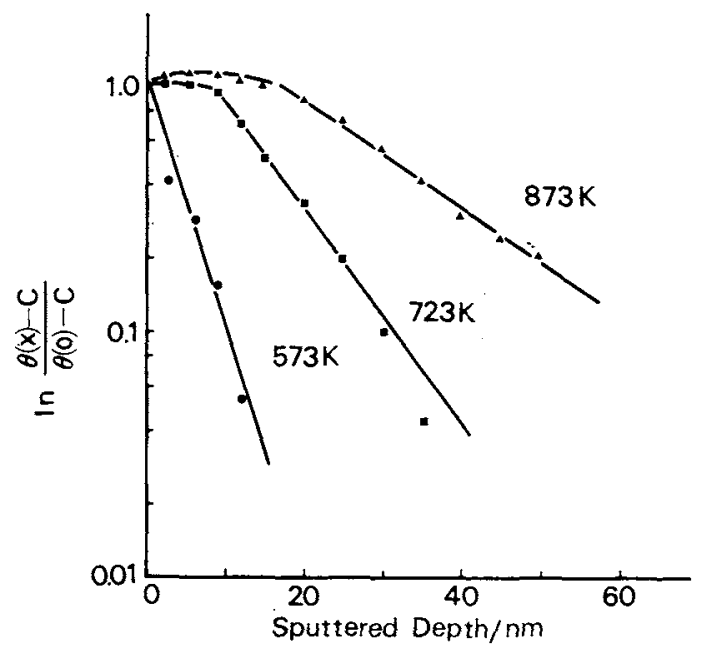

Fig.7 The analysis of the sputter-enhanced diffusion coefficients by eq. (2). 
た。 $573,723,873 \mathrm{~K}$ での促進された銅の抎散定数 $D *$ は $6.8 \times 10^{-19}, 1.5 \times 10^{-18}, 3 \times 10^{-13} \mathrm{~m}^{2} / \mathrm{s}$ と求まった.

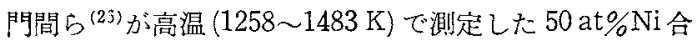
金中の銅の自己拡教のデータをロで，また外括した結果を 破線でFig.8 中に示した。外插に用いた活性化ェネル ギーと頻度因子ばそれぞれ $253.3 \pm 1.3 \mathrm{~kJ} / \mathrm{mol}(60.3 \pm 0.3$ $\mathrm{kcal} / \mathrm{mol}),(2.3 \pm 0.1) \times 10^{-4} \mathrm{~m}^{2} / \mathrm{s}$ である. $573,723,873 \mathrm{~K}$ での体拡散定数はそれぞれ $1.9 \times 10^{-27}, 1.2 \times 10^{-22}, 1.6 \times$ $10^{-19} \mathrm{~m}^{2} / \mathrm{s}$ であるから, 各温度での㹡散の促進度合は 3.6 $\times 10^{8}, 1.3 \times 10^{4}, 19$ となり低温になるほど両者の抎散定数 の差は著しくなる。また促進された拡散定数 $D^{*}$ は 573 $873 \mathrm{~K}$ の範困で温度の逆数に対しかなり良い直線性を示し ていて，アウレニウス式従うとしてこの勾配から活性化 エネルギーを算出すると $22.6 \mathrm{~kJ} / \mathrm{mol}(5.4 \mathrm{kcal} / \mathrm{mol})$ であ った。この值は正常な体払散の活性化ェネルギーの1 100 下であり，粒界抬散定数の值と比皎してb小さい.空孔型拡 散に比較してイオン誘起抓散の温度依存性が極めて小さい

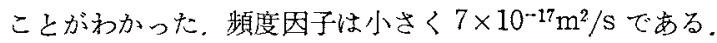

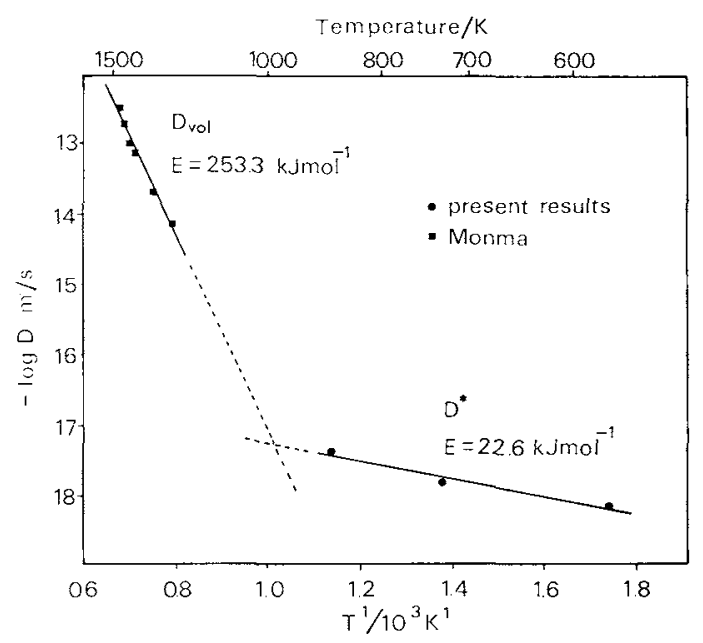

Fig.8 The effect of temperature on the enhanced diffusion coeffcients of a coarse grained 40 at $\% \mathrm{Ni}$ alloy (diameter $1 \sim 2 \mathrm{~mm}$ ). The normal diffusion coefficients were reported by Monma et al. ${ }^{(26)}$.

\section{6. 此例定数 $\boldsymbol{R}$ の温度ならびにイオン密度依存性}

Fig.2で示したように室温スパッタリングによる組成変 化に対して成立した式（1）は高温でもかなり良い精度で成 立した，定数 $R$ の内容を検討するために， $R$ の温度とイ オン密度依存性とを 40 at $\% \mathrm{Ni}$ 合金粗大粒試料を用いて測 定した.イオン密度は $4 \times 10^{-3} \sim 8 \times 10^{-1} \mathrm{~A} / \mathrm{m}^{2}$ の範团, 温 度は $573,723,873 \mathrm{~K}$ の 3 点を選んだ。各温度とイオン密 度との組合わせ対し $3.6 \mathrm{ks}$ イオン衝揧を行った後, 表 面組成を AES で求め式(1)KよりRを算出した結果を Fig.9に示した， $f(T, I)$ Kついて考察で述べる。

低イオン密度の場合には銅の偏析効果が大きいたかに， $R$ は室温での値 1.9 (破線)より小さく，その傾向は高温に

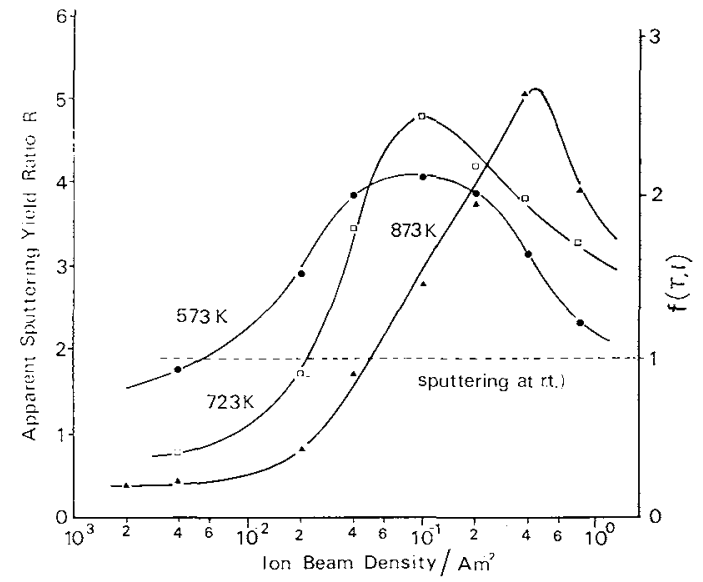

Fig.9 The apparent sputtering yield ratio and the temperature coefficient calculated by eq. (1) and (3) of a coarse grained 40 at $\% \mathrm{Ni}$ alloy (diameter $1 \sim 2$ $\mathrm{mm}$ ) as a function of sputtering temperature and ion density. Measurement was performed after sputtering for $3.6 \mathrm{ks}$.

なるほど強い，ただし本研究では照射時間が短いために平 衡組成值が得られていなく，長時間照射を行えば $R$ は大 くなると考无らる.イオン密度の增加につれて $R$ は急激 に大きくなり，破線を越光やがて最大值を示寸。それらの 值は $573,723,873 \mathrm{~K}$ でそれでれ 4.1,4.8,5.3である。 またこのときのイオン密度は $8 \times 10^{-2}, 1 \times 10^{-1}, 4 \times 10^{-1}$ $\mathrm{A} / \mathrm{m}^{2}$ である。高温になるほどRは大きくなるが，ほぼ $873 \mathrm{~K}$ で飽和してくる、イオン密度をさらに大さくすると $R$ は次第に減少し始め，最終的には破線の值に近つくもの と考えられるが，その減少のし力は高温になるはとゆるや かである。その他 $R$ の変化は結晶粒径によって子影響さ れ，細粒になるほど同じ照射条件では $R$ は小さくなが， その影響が現われるのは $723 \mathrm{~K}$ 以上であった

\section{IV. 考察}

銅ニッケル合金の高温スパッタリングの機構を解明する ためには次の 4 点を明らかにする必要がある。(a) 銅と二 ッケル単体のスパッタ率の温度依存性，(b) 銅の照射誘起 表面偏析，(c) 銅の照射誘起抬散，(d) 金属組織の影響。

\section{1. 銅とニッケルのスパッ夕率の温度依存性}

高温スパッタによるニッケル富化現象が, 銅とニッケル のスパッタ率とのすのが温度変化したことによって起った かどらかを㛟討する必要がある，単体のスパッタ率の温度 依存性に関する報告は少ない。Nelson ${ }^{(27)}$ は $7.2 \times 10^{-15}$ J (45 keV)のゼノンイオンによる銅のスパッ夕率を测定 し, $873 \mathrm{~K}$ を゙は温度依存性が無いるののそれ以上では急 激に大さくなると報告している，Kaminsky ${ }^{(28)}$, Carter と Colligon ${ }^{(29)}$ によれば，少なくとる本研究で扱った温度範用 では銅とニッケルに関して顕著な温度依存性は無いと指摘 されている、いずれの結果すイオンエネルギーが高いので, 
その委類推して良いかどらかは問題点として残る。最近 Shikata と Shimizu ${ }^{(19)}$ は水晶膜厚計を用いて, $8 \times 10^{-17} \mathrm{~J}$ $(500 \mathrm{eV})$ のアルゴンイオンによる銅のスパッタ率を測定 し，前述同様の結論を得た。結局スパッ夕率比は少なくと る $873 \mathrm{~K}$ 程度までは 1.9 の值が保たれていると考克られ る。徒って式(1)中のパラメター $R$ は，高温ではスパッ 夕率のみかけの变化を示すもので，温度とイオン密度低存 性考考虑して次式の上うに書き改められ

$$
R=f(T, I) \cdot R_{0}=f(T, I) \cdot r / s
$$

となる。ただし $R_{0}$ は室温での銅とニッケルのスパッタ率

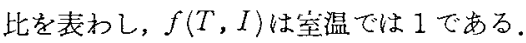

\section{2. 銅の照射誘起表面偏析}

銅の表面偏析が起ることは AES, ISS, SIMSなどの奏験 によって明らかにされ，熱力学的な検討もなされている。 $\mathrm{Ng} ら^{(30) \sim(32)}$ は原子プローブ電界イオン顕微鏡(AP-FIM) を用いて，Ni-3.1士0.5 at％Cu 合金の熱平衡なった最

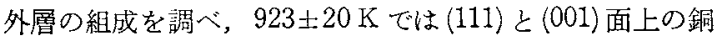
濃度は $17 \pm 2.7$ at\%, $36.6 \pm 7.5$ at\% と求めた。 この濃度 は表面の熱力学データによる計算値と良い一致を示すこ と，富化領域は 4 5 原子層の厚みがあると報告している。 本研究て $873 \mathrm{~K}$ の焼鈍によって得られた銅の濃度は， Ng らの計算による值より低いが，これはAESの分析深さが $1.5 \mathrm{~nm}$ 程度あるために平均化されたことによると考兄ら れる。

銅の偏析膡の厚みの推定には，本研究ではイオン踏離法 を用いているために，その精度は击まり高くないが5〜 6

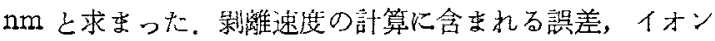
ミキシング效果を考虑しても銅富化層の厚みは $\mathrm{Ng} ら に よ$ るギブスの平衡偏析から予想される值よりはるかに大き

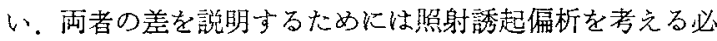
要がある. Ishitani とShimizu ${ }^{(33)}$ が行ったモンテカルロ

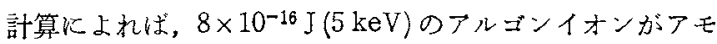
ルフォス様の銅に入射した場合の飛程は $5 \sim 7 \mathrm{~nm}$ で, ノッ クオン原子も衝突を繰り迈しているため，この領域には多 数の原子空孔や格子間原子が形成される。高温スパッタ中 苏るいは焼鈍によりこれらの金属組織が回復するときに偏 析が起ると考兄られる. $873 \mathrm{~K}$ での搪散定数は先に示した ように〜 $10^{-18} \mathrm{~m}^{2} / \mathrm{s}$ であるから，拡散距離は数秒間で $\sqrt{D \cdot t}$

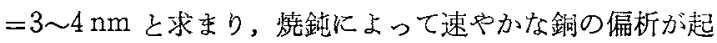
るためには，イオン照射による格子の乱が必要と考光られ る、イオン衝撃を受けた表面には室温でもギブスの平衡偏 析による薄い銅の富化層が形成されている。Okutani ら (11) は $50 \mathrm{at} \% \mathrm{Ni}$ 合金の室温でイオン衝撃後の表面を AES と ISS で調べ，それぞれの手法で求めた組成は $62 \pm 2$ at $\% \mathrm{Ni，}$ $39 \pm 6$ at\% $\% \mathrm{Ni}$ であった。選択スパッタリングにより表面近 傍の平均組成はニッケルの富化したことを示すが，最外一 層では母相より銅が多い.イオン衝撃中もしくは停止後た だらに銅が最外層へ拡散したことを示す。このことは本研
究で得た拡散定数からも裏付けられた。室温での外挿した 拡散定数は $8 \times 10^{-21} \mathrm{~m}^{2} / \mathrm{s}$ であるから数秒間で $1 \sim 2$ 原子 層の距離を銅虫㹡散することが出来る。ここで用いた拉散 定数は Fig.7 中の深い領域の欠乏層から求めたもので，表 面近傍では更に速い桩致が起ることを考机ば，平衡偏析に よる銅富化層の存在は理解出来る。

以上の点を総合して考えると，まずこの合金の最外䅉に 銅が富化し易いといら熱力学的な性質があり，これに対し 入射イォンは表面近傍化多数の格子久陥を作ることで照射 誘起払散を起し，また高温では銅の照射誘起偏析を起して やや厚い銅富化層を形成したと考ることが出来る。

\section{3. 拡散促進罾の存在とその温度依存性}

イオン照射により拡敞が促進された領域は 2 種類ある。 1 つは表面に近いところに出来て入射イオン密度の影響が 少ない.1次イオンやノックオン原子によって格子が乱され たことに寄因する昖散で,活性化エネルギーは大きい。これ に対し深いところで形成された欠之層は，表面近傍と母相 との濃度差によるもので，表面近くの損傷頜域から流れて きたニッケルの格子間原子による㧪散機構が主なものと考 えられる。つまりニッケルの格子間原子は入射イオンの飛 程上りはるかに深いところまで侵入し，格子位置の銅原子 と置換する。この銅原子は再び格子間执散機構で表面近傍 に流れてゆくなめに，深い欠乏層もしくはニッケル富化層 が形成された。このモデルの妥当性については今後詳細な 検討を行う必要があるるのの，拡散の活性化エネルギーが 極めて小さいことはモデルを支持する有力な根拠となる。

\section{4. 金属組織の影郎}

高温スパッタリングによる銅欠乏層の形成については,

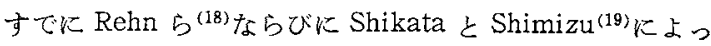
て報告されているが，その深さは本研究で得心結果と異な っている.Rehn らが得た欠之層は $673 \mathrm{~K}$ 以上で観測され， $923 \mathrm{~K}$ では数 $\mu \mathrm{m}$ になった。 $673 \mathrm{~K}$ 以下で久乏層が認めら れなかったのは，イ才ン照射に $8 \times 10^{-16} \mathrm{~J}(5 \mathrm{keV}), 1.25$ $\mathrm{A} / \mathrm{m}^{2}$ のイオンを用いたためで，式(2)中の $v$ が大きく Fig.9 から示されるよらに䟝離速度に欠之層の形成が追 付かなかったと考光られる。一方 $923 \mathrm{~K}$ での欠乏層が深

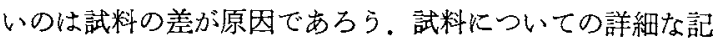
述は無いが，蒸着膜を用いた可能性が高く，この場合には 粒界の寄与が無視出来なくなる。特にその影響は $723 \mathrm{~K}$ 以 上では著しいことを考れば両者の差を説明出来る。

一方 Shikata らの得た久乏層は $473,573,673 \mathrm{~K}$ でそれ ぞれ数十nm, 数百 $\mathrm{nm}$, 数 $\mu \mathrm{m}$ で本研究で得た值より $1 \sim 2$

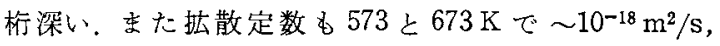
$\sim 10^{-17} \mathrm{~m}^{2} / \mathrm{s}$ と䄪 1 桁大きい. 実験条件の差として, イオ ン密度が本研究より 1 妳小さく，加速エネルギーは $8 \times$ $10^{-17} \mathrm{~J}(500 \mathrm{eV})$ で約 $1 / 6$ であるから，式 (2)中のvがかなり 小さくその結果深い欠乏層が形成されたと考党られる。し 
かし欠乏畨の深さの温度低存性は 100 度每に 8〜10 倍とな り，本研究の150度每に2 倍という結果とは異なる。式 (2)によって拡散定数を概算してみると， $473,573,673 \mathrm{~K}$ では去れぞれ $2 \times 10^{-19}, 9 \times 10^{-18}, 5 \times 10^{17} \mathrm{~m}^{2} / \mathrm{s}$ と求まり報 告された値とはオーダー的には一致している。先に温度依 存性が大きいことを示したが，活性化エネルギーは約 46.2 $\mathrm{kJ} / \mathrm{mol}(11 \mathrm{kcal} / \mathrm{mol})$ で本研究で得た值の約 2 倍である. 結果の異なりを説明するためには久之層の入射イホン密 度，加速エネルギー依存性を検討する必要がある。そのこ とによって㷂射新起拡散走数の物理的内容を明らかにする ことが出来る。

試料による差としては，金属組織の影辢を考虑する必要 がある，先に述べた平均精径て上る粒界拡放の奇与の他に 集合組織の間題がある。 $f c c$ 金属中での拉散は本来等方的 であるが，入射イオンがチャンネりング効果を持つために 拡散の促進度合に異方性が現方れ，その結果銅欠乏層の深 さは各結晶粒の方位によって異なることが確瑟されている。 ただしチャンネリング効果とスパッタ率の方位依存性は逆 向の傾向があり，樑さ力向分布を澌定主る過程でスハッタ 率の差から見かけ上の差を生む可能性むある。電子チャン ネリングパターン法 (ECP)を用いて詳細に検討する必要が ある。もし欠之層が結晶方位依存性を持つとすれば，試料 の作成条件によっては集合組織が異なり，平均知乏層の深 さに差が出ることは十分考无得ることである(34).

\section{5. 比例定数 $\boldsymbol{R} の$ 变化}

式(1)，(3)が合金の広い組成範围に対して高温でる成 立することは，表面近傍の組成が内部と買なったこと，特に 照射誘起偏析によるみかけの現象である。イオン密度が低 い場合には銅の偏析效果方現わ秃て, $R$ は小さく $f(T, I)$ も 1より小さくなる、亦たイオン密度の増加に伴い $f(T, I)$ は 1 近つく，しかし銅が椇傷層内に均一に分布し銅富化 合金を作ったをすれば， $f(T ， I)$ はを決して超えない等 である. $f(T, I)$ が 1 より大きな值を取ることは，銅の分 布が一様でなく、ニッケルの実効的なスパッタ率を低くし ニッケル富化層が表面近くに出来たことを意味する。 $f(T, I)$ の最大值は温度が高くなるにつれて大きくなるが， 拡散速度が大きくなるにすかかわらず 873〜973 K で平衡 值になることは，Rが表面近傍の熱力学的性質で決る点を 考慮すれば理解出来る。そのため母相組成によって体执散 定数が変化しても表面組成変化は均一な $R$ の值で説明出 来，拡散定数の差はむしろ久乏層の深さに影響すると考え られる。

本研究を潐めるにあたり，終始温かい御指導と有益な御 討論をいたたいた電子技術総合研究所極限技術部長 中山 勝矢博士，同部宇宙環境技術研究室長 小野雅敏博士，貴 重な試料を提供して下゙さった東北大学金属材料研究所教授 広川吉之助先生，X線マイクロアナライザーの利用に便宜 訪計っ下さった東京大学生産技術研究所助教授 安井 至 先生，選択スパッタリングのご討論をいただいた大阪大学
工学部助教授志水隆一先生に深く感謝致します，筆者の 1 人清水 肇厄は昭和 55 年度東京大学生産技術研究所流 動妍究䝿の機会を与えられた。ここに謝意を表わします。

\section{文献}

(1) M.L.Tarng and G.K.Wehner : J.Appl. Phys., 42 (1971), 2449.

(2) K.Nakayama, M.Ono and H.Shimizu : J.Vac. Sci. Tech., 9(1972), 749 .

(3) H.Shimizu, M.Ono and K.Nakayama : Surf. Sci., $36(1973), 817$.

(4) K.Watanabe, M.Hashiba and T.Yamashina: Surf. Sci., $69(1977), 721$.

(5) P.S.Ho, J.E.Lewis, H.S.Wildman and J.K. Howard : Surf. Sci., $\mathbf{5 7}(1976), 393$.

(6) P.S.Ho : ibid., 72 (1978), 253.

(7) N.Saeki and R.Shimizu : Jpn. J.Appl. Phys., 17 (1978), 59.

(8) K.Goto, T.Koshikawa, K. Ishikawa and R. Shimizu : J.Vac. Sci. Tech., 15(1978), 1695.

(9) T.Koshikawa, K.Goto, N.Saeki, R.Shimizu and E.Sugata : Surf. Sci., 79(1979), 461.

(10) H.H.Brongersma, M.J. Sparnaay and T.M. Buck: Surf. Sci., $71(1978), 657$.

(11) T.Okutani, M.Shikata and R.Shimizu : Surf. Sci., $99(1980)$, L410.

(12) 柿林博士, 毛利衛, 渡辺国昭, 山科俊郎: 真空, $22(1979), 220$.

(13) N.Saeki and R.Shimizu : Surf. Sci., 71 (1978), 479.

(14) H.Shimizu, M. Ono and K.Nakayama : J.Appl. Phys., $46(1975), 460$.

(15) H.Shimizu, M.Ono, N.Koyama and Y.Ishida : Jpn. J.App1. Phys., 19(1980), L567.

(16) H.Shimizu, N.Koyama and Y.Ishida : ibid., 19 (1980), L671.

（17）清水 肇, 古山直行，石田洋二，小野雅敏, 工藤 隆一：日本金属学会誌，45(1981)，210.

(18) L.E.Rehn, S.Danyluk and H. Wiedersich : Phys. Rev. Lett., 43(1979), 1437.

(19) M.Shikata and R.Shimizu : Surf. Sci., 97 (1980), L363.

(20) Y.Takasu, H.Shimizu, S.Maru, M.Tomori and Y.Matsuda : Corr. Sci., 16(1976), 159.

(21) M.Ono, H.Shimizu and K.Nakayama: Surf.Sci., $52(1975), 681$.

（22）清水 籔，判治克己，石黒勝彦，本間視一：日本金 属学会誌, 42(1978), 1071 .

(23) R.R.Olson and G.K.Wehner : J.Vac.Sci. Tech., $14(1977), 319$.

(24) K.Watanabe, M.Hashiba and T.Yamashina: Surf. Sci., 61 (1976), 483.

(25) A.H.Eltoukhy and J.E.Greene : J.Appl. Phys., $51(1980), 4444$.

（26）門聞改三，須藤一，及川 洪：日本金属学会誌, $28(1964), 192$.

(27) R.R.Nelson : Phil. Mag., 11 (1968), 291.

(28) M.Kaminsky : Atomic and Ionic Impact Phenomena on Metal Surfaces, Springer-Verlag, Berlin, (1963) .

(29) G. Carter and J.S.Colligon : Ion Bombardment of Solids, Heinemann Educational Books, London, (1969).

(30) Yee.S.Ng, T.T.Song and S.B.McLane, Jr. : Phys. Rev.Lett., 42 (1979), 588.

(31) Yee S.Ng, T.T.Song and S.B.McLane, Jr. : Surf. Sci., 81 (1979), 31.

(32) Yee S.Ng, T.T.Song and S.B.McLane, Jr. : J. Vac. Sci. Tech., $17(1980), 154$.

(33) T. Ishitani and R. Shimizu : Phys. Lett., 46A (1974), 487.

（34）清水 肇, 古山直行, 石田洋一: 未発表。 